\title{
Josep M. Rovira Belloso \\ OS SACRAMENTOS: SÍMBOLOS DO ESPÍRITO \\ São Paulo, Paulinas, 2005
}

Dalton Sebastião Brandão*

A obra do professor Belloso, ${ }^{1}$ Os sacramentos: símbolos do Espírito, surpreende-nos quer pela clareza, quer pela precisão no desenvolvimento do tema. Ela é composta de oito capítulos recheados de informações que, além de demonstrar a sua grande pesquisa, revela a sua espiritualidade, chamando a atenção para a vida concreta. Fé sem vivência resulta em erudição vazia, desnecessária.

A sua proposta parte do grande desafio de refletir sobre os sacramentos num mundo marcado pela secularização: tantos símbolos empregados, porém vazios dos verdadeiros significados.

Com maestria propõe a compreensão dos sinais e dos elementos utilizados na liturgia, tendo à frente o grande desafio do modelo eclesiológico a ser seguido.

Há uma grande preocupação com as antíteses: evangelização e sacramentalização, dom de Deus e resposta humana, magia e gratuidade de Deus, realismo e simbolismo; que precisam ser analisados para que saibamos unir fé, como mistério celebrado, e vida comprometida.

* Professor da Pontifícia Faculdade de Teologia Nossa Senhora da Assunção - São PauloSP. Licenciado em Filosofia e mestre em Teologia Espiritual

1 Licenciado em Direito e doutor em Teologia. Emérito da Faculdade de Teologia da Catalunha. 
Resgata-se, na obra, o discipulado/seguimento de Jesus Cristo para uma autêntica vivência/celebração dos sacramentos, bem como entende-se o mistério de Deus a partir da sacramentalidade de Cristo e da Igreja.

\section{A REALIDADE COMO PONTO DE PARTIDA}

O professor Belloso descreve a não-compreensão do que sejam os sacramentos, denunciando a concepção popular que os acentua como atos próximos à magia.

Mostra a grande contribuição da perspectiva pós-conciliar quando valoriza o Concílio Vaticano II, a volta às origens, principalmente aos Padres da Igreja, bem como o desenvolvimento da teologia recente.

Na parte histórica, relembra a imposição dos sacramentos como elemento para ser cidadão espanhol, e poderíamos dizer que o mesmo aconteceu em culturas de maioria católica, para serem considerados pessoas dignas.

É notório o pouco valor dado à religiosidade popular e, com isso, o distanciamento da mesma da teologia oficial.

Enfatizou-se mais a opção ou compromisso dos pais das crianças do que aquilo que era celebrado nos sacramentos. Há mais motivações sociais do que uma fé comprometida comunitariamente.

Os sacramentos, a partir da fé comprometida, são muito mais que ilustrações pedagógicas, pois eles supõem a ação do Cristo Ressuscitado.

Ressalta-se, profundamente, a humanidade dos sacramentos, mostrando a correlação existente entre a estrutura do sacramento e a estrutura da pessoa humana. Há, desse modo, uma certa conformidade entre a espiritualidade e a vida corporal.

Para concluir esta parte, citando santo Tomás de Aquino, ele nos diz como o sacramento está no nível do signo. Introduz, assim, o conceito de símbolo, pela integração do intelectual e do afetivo, pela profunda relação entre corporalidade e espiritualidade humanas, devendo tender para a unidade.

Os sacramentos adaptam-se como símbolos porque situados entre a terra e o céu, também para a nossa cultura atual, são apropriados ao modo de ser da pessoa humana. 


\section{REFLEXÃO TEOLÓGICA}

\section{As novidades}

São apresentadas três novidades principais para a elaboração da teologia sacramental atual.

A primeira fala da perspectiva escatológica que toda teologia precisa ter, acentuando, particularmente, a eclesiologia.

A segunda ressalta a perspectiva trinitária, dando a devida importância para a conexão dos sacramentos com Cristo Ressuscitado e com o Espírito Santo.

E a terceira, por fim, fala da perspectiva simbólica, lembrando que, no pensamento católico, o escatológico, o divino, o invisível vem antes, e deve ser apresentado através daquilo que é visível e organizado.

Há uma preocupação em ter uma Igreja totalmente livre dos poderes do mundo e profundamente fiel na comunhão com a Palavra de Deus, com a oração, com a eucaristia, com os seus pastores e com os pobres e marginalizados. Através desse compromisso/comunhão, ela expandirá para o mundo as energias da fé e do amor.

Após essas três perspectivas, a reflexão cresce apontando o papel do Espírito Santo na sacramentalidade cristã, indo, profundamente, na riqueza da reflexão patrística. Os Padres da Igreja são citados e comentados com clareza, e a contribuição feita por eles é resgatada totalmente.

Em seguida, aborda a dimensão histórica para entendermos a evolução do pensamento teológico sacramental.

Mostra a imprevisibilidade daquilo que se dá gratuitamente e aponta para o símbolo como chave imperativa para a compreensão do estudo realizado por ele, demonstrando que o espiritual é transmitido pelo símbolo.

Conclui que os sacramentos da Igreja devem ser vistos como símbolos do Espírito.

\section{Os conceitos fundamentais}

Inicia com um estudo sobre os sete conceitos básicos e fundamentais para a teologia sacramental: o mistério, o signo, o símbolo, o sacramento, o culto, a celebração e a fé. 
Ao explicar o mistério, apresenta-o como algo maior que uma idéia ou pensamento, situa-o como o desígnio universal de salvação do Pai, revelado e realizado em Jesus Cristo.

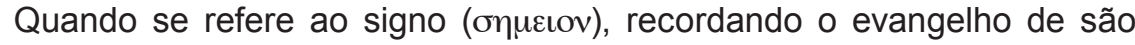
João, diz que "é aquilo que, uma vez visto, leva a crer" e "o signo permite ver e crer porque é a interseção da intervenção divina com a visibilidade humana" (p. 45).

Depois, cita Orígenes, lembrando que "há signo quando aquilo que se vê indica alguma coisa (que não se vê)" (p. 53).

A partir desse ponto, realiza uma excelente pesquisa nos Padres da Igreja, bem como confronta os conceitos antigos com os atuais, até mesmo da filosofia atual, para recuperar o sentido correto de símbolo aplicado aos sacramentos, principalmente à eucaristia.

Em seguida, define culto e celebração com a preocupação de eliminar desses conceitos todas as visões de ações mágicas, tendo presente o seu aspecto festivo/comunitário, bem como de aliança, somente entendido a partir da maturidade cristã. A verdadeira maturidade cristã só se alcança quando se compreende a cruz na sua profundidade teológica, soteriológica e antropológica.

Termina explicando a fé como antecipação das coisas que esperamos e também como comunhão com Deus. Consegue elaborar a correlação simbólica entre fé e sacramentos, pela presença da antecipação e esperança que suscitam.

\section{Visão histórica}

Partindo da polêmica católico-protestante sobre os sacramentos, é feita uma rica exposição histórica com a recuperação dos aspectos teológicos, acentuando e discutindo os erros e os acertos de ambas as partes. Como bom professor, o autor expõe didaticamente toda a argumentação sem cansar o leitor. Ao contrário, convida-o a um maior aprofundamento histórico-teológico do assunto.

Em seguida, são apresentadas as principais correntes católicas do século $X X$, lembrando o esforço feito na teologia católica para explicar, convincente- 
mente, "a função dos sacramentos na vida cristã como ações de Cristo que comunicam a graça de Cristo aos que os recebem com fé" (p. 111).

As principais correntes apresentadas são: Dom Odo Casel: teoria dos mistérios (com suas riquezas e seus limites); Schillebeeckx: Cristo Glorioso é o sujeito que atua nos sacramentos); J. Ratzinger (atual papa Bento XVI): visão cósmica e histórica; Juan Luis Segundo: teoria da imagem pedagógica (sensibilidade com a teologia latino-americana, acentuando o aspecto da conscientização trazido pelos sacramentos); J. Piaget: teoria do jogo (muito mais na linha pedagógica); A. Ganoczy: teoria da comunicação; por fim, Eberhard Jüngel, Bruno Forte e outros: teologia simbólica.

Conclui trabalhando a interligação do símbolo com o rito: "O rito é a perpetuação eclesial do símbolo" (p. 137) e "os símbolos são percebidos através dos sentidos, mas afetam o centro da pessoa" (p. 139).

\section{Os sacramentos na Igreja}

Primeiramente, vemos o conceito de Aliança comunicado numa linguagem mais acessível.

Depois, os sacramentos aparecem como oração da Igreja, com clareza para transparecer a luz que Jesus irradia. Há, sempre, a preocupação para não cair na clareza fria do racionalismo como expressão de conhecimento.

Em seguida, os sacramentos são colocados com âmbitos do Espírito Santo, devendo suscitar especialistas em humanidade: "Especialistas na vida e na morte, no sofrimento e na alegria, no amor e na reconciliação" (p. 155), como se expressava o papa Paulo VI.

O testemunho e a missão tornam-se imprescindíveis, mas na consciência segura de que são possíveis pelo Espírito dado por Cristo.

Celebração, vida e seguimento de Cristo vêm intimamente associados ao amor fraterno.

A multiplicação do verdadeiro pão expressa-se no pão da Palavra, da eucaristia e do amor fraterno.

Tradição, criatividade e inculturação jamais devem estar dissociadas, mas intimamente unidas, para refletir uma liturgia celebrada nas condições favoráveis a uma evangelização. Deve-se lembrar que "a celebração não 
é obra do ser humano, mas ato de Jesus (tradição); que cada celebração deve respeitar seu verdadeiro contexto social e cultural (criatividade e inculturação)" (p. 159).

Termina demonstrando a distinção entre celebração (vida) e teatro (ficção). Na vida, ocorre a comunhão real e espiritual que se alcança na liturgia. No teatro, isso não é possível.

\section{Os sete sacramentos}

Os sacramentos são estudados a partir da perspectiva do símbolo. O batismo e a eucaristia ganham atenção especial e aos demais sacramentos são feitos alguns acenos, devido à elaboração feita em outros estudos e artigos, pelo autor, em outros lugares.

Para dimensionar uma nova visão dos sacramentos, alguns elementos são muito destacados:

a) a revalorização das catequeses mistagógicas sem idealização (retorno à patrística);

b) a preparação catequética deve ser homogênea com a celebração; e

c) trabalhar a liturgia para que seja autotransparente, baseada na força da Palavra e dos símbolos.

O batismo, por ser a porta da Igreja e dos demais sacramentos, deve destacar três símbolos principais que constituem a sua essência visível: a imersão, a iluminação e a unção.

Deve-se explicar muito claramente a impressão de caráter e a pertença ao Povo de Deus.

Fala muito pouco da confirmação. Lembra, apenas, o compromisso de atuação do cristão no mundo para viver o seu batismo de forma madura.

Já na eucaristia há a acentuação escatológica, sem prejuízo ou contraposição da dimensão de memória.

Apresenta os principais pontos teológicos da encíclica Mysterium fidei, de Paulo VI, recordando que a eucaristia é o cume da vida cristã e não espetáculo. Ela faz a Igreja e é fonte da unidade eclesial.

192 ReVISta de Cultura TeOLógICA - V. 15 - N. 58 - JAN/MAR 2007 
Antes de entrar em alguns acenos sobre os demais sacramentos, o próprio autor diz que "este livro pode ser considerado uma longa meditação sobre a frase de Tomás de Aquino: ' $O$ sacramento situa-se no gênero do signo"' (p. 201).

Aos demais sacramentos são reservadas algumas reflexões, somente do ponto de vista do pensamento simbólico: a penitência como "segunda tábua" de salvação depois do batismo, lembrando que se está introduzindo a pessoa no seio da misericórdia divina e nunca em um tribunal humano; a unção dos enfermos como aceitação e cura da debilidade própria dos enfermos ou anciãos, ressaltando "o consolo que é fruto da 'compaixão' de Deus" (p. 211); na ordem, "a imposição das mãos, além de significar a invocação/transmissão do dom do Espírito Santo (como nos demais sacramentos), significa a concessão de uma função espiritual específica, a de santificar: é o ato de estabelecer o candidato no ministério ordenado" (p. 214); finalmente, o matrimônio, simbolizando a relação de Cristo com a Igreja, concentra-se no amar e entregar-se, purificar e santificar um ao outro (marido e mulher), e tem a sua união indissolúvel pelo amor fiel: "O matrimônio cristão é uma força da natureza. Todavia é, acima de tudo, uma graça que vem de Deus" (p. 218).

Quando pensamos que a reflexão chega ao fim, o autor brinda-nos com a reflexão do lava-pés, que, para muitos da Idade Média, era tido como um sacramento.

O autor explica-nos que "não é um sacramento, mas um símbolo da forma de vida que a caridade assume" (p. 219).

Termina o estudo afirmando três pontos:

1. "A estrutura simbólica dos sacramentos é análoga à estrutura também simbólica da caridade exercida" (p. 219).

2. 'O amor fraterno é a forma de todas as 'obras de misericórdia', nas quais conta, decisivamente, o elemento material" (p. 219).

3. "O Espírito Santo é a graça última - o dom supremo - tanto dos sacramentos como da caridade exercida" (p. 220). 


\section{Apreciação}

Durante a análise da obra, fui, aos poucos, fazendo a apreciação de vários elementos.

Agora, desejo, apenas, destacar quatro pontos:

1. A obra é científica sem perder sua didática. É fácil de ser lida, encanta e tem espiritualidade.

2. Há uma valorização constante da Escritura e da tradição, com muita elaboração teológica sadia e contextualizada.

3. No final da obra, vemos uma boa bibliografia para um aprofundamento do tema, com consistência.

4. Por fim, é uma pena que poucos possam deliciar-se com as expressões latinas, com sua lógica, precisão e beleza. Talvez seja a única barreira para alguns leitores, mesmo que as idéias venham logo explicadas.

Foi e será sempre um prazer voltar à leitura de Os sacramentos: símbolos do Espírito, quer pelo conteúdo, quer pela estrutura didática, mas, principalmente, pela espiritualidade que contém. 